\title{
A Lexical Analysis of Zechariah 6:1-8
}

\author{
Philip Suciadi Chia ${ }^{1)}$ Juanda $^{2)}$ \\ 1) Southern Baptist Theological Seminary - Kentucky USA \\ E-mail: pchia275@students.sbts.edu \\ 2) Evangelical Theological Seminary of Indonesia - Surabaya \\ E-mail: juanda@sttii-surabaya.ac.id
}

\begin{abstract}
Zechariah 1:1-6 summarizes a speech to the people that reports the failure of the previous generations to heed the message of the prophets who God has sent while successfully challenging the current generation to turn to YHWH. The eight visions of the second block (1:7-6:15) share common compositional elements, but they also show evidence of later reworking. The third block, Zechariah 7-8, constitutes a collection of short sayings dated approximately two years after temple construction began.

Zechariah 6:1-8 could be divided into two sections. First is disclosure of the vision (6:1-4) and the last one is the disclosure and explanation of the vision (6:5-8). Particularly, in this first subparagraph, Zechariah seems to present his thoughts in chiasmus. This chiasmus has a structural function which often a chiastic couplet is used to both open and close a stanza or poem. Zechariah introduced his eighth vision with four verbs, which are thematic words.
\end{abstract}

Keywords: Zechariah, Vision, Generation

\section{Translation}

v. 1 I returned and I lifted my eyes and saw, and behold, four chariots came out from between two mountains. And the mountains were mountains of bronze.

v. 2 The first chariot were red horses, the second chariot were black horses,

v. 3 The third chariot were white horses, and the fourth chariot were dappled horses--all of them strong.

v. 4 Then I answered and said to the angel who talked with me, "What are these, my lord?"

v. 5 And the angel answered and said to me, "These are going out to the four winds of heaven, after presenting themselves before the LORD of all the earth.

v. 6 The one with the black horses - they are going to the north country, the white ones go after them, and the dappled ones go toward the south country."

v. 7 When the strong horses came out, they sought to go and patrol the earth. And he said, "Go, patrol the earth." So they patrolled the earth.

v. 8 Then he called out to meand he said to me, saying "Behold, those who go toward 
the north country have appeased my wrath in the north country."

Exegetical Idea

Subject:

The Vision of four

chariots

Complement: The Disclosure and explanation

Full Statement: The Vision of four chariots; The disclosure and explanation.

\section{Exegetical Outline}

\section{The Disclosure of four chariots \\ II. The Explanation of four chariots}

\section{Historical Background}

The prophet Zechariah served in the latter half of the sixth century (in 520 BC), some twenty years after the first Jews returned from exile in Babylon. ${ }^{1}$ In his time, the exiles fell far short of promising the return and restoration of Israel's fortunes after exile. In respect to this situation, Zechariah called the people to trust and obey God's word.

His writing presents Zechariah as one who challenges the people of his generation to turn to YHWH (1-2), as a visionary who seeks to interpret temple reconstruction and polity (1:7-6:15), and as a figure of authority to be consulted on religious and political matter (7-9).

The lineage, in $1: 1$, helps to situate

${ }^{1}$ Anthony R. Petterson, Haggai, Zechariah \& Malachi (Downers, Illinois: InterVarsity Press, 2015), 91.
Zechariah as a member of a prominent, postexilic, priestly family. These priestly connections could have aided Zechariah's status and would also account for why Zechariah speaks in 7:4 in response to reportedly delivered to the priests according to $7: 3 .^{2}$

\section{Literary Form}

Structurally, Nogalski proposes that Zechariah divides into five discrete sections. Of these five units, only the first (1:1-6) is not a composite unit containing either multiple episodes or disparate compositions.

Zechariah 1:1-6 summarizes a speech to the people that reports the failure of the previous generations to heed the message of the prophets who God has sent while successfully challenging the current generation to turn to YHWH.

The eight visions of the second block (1:7-6:15) share common compositional elements, but they also show evidence of later reworking. The third block, Zechariah 7-8, constitutes a collection of short sayings dated approximately two years after temple construction began (compare 7:1 with 1:1, 7).

2 James D. Nogalski, The Book of The Twelve Micah-Malachi (Macon: Georgia: Smyth \&Helwys, 2011), 805. 
These sayings are thus grouped thematically and framed by a report of dialogue between the prophet and the priests on the one hand and a delegation from Bethel on the other. Finally, Zechariah 12:14 also begins with its own superscription, but it deals exclusively with the fate of Jerusalem, Judah and the nations following the eschatological battle, without ever addressing the former Ephraimite territories. $^{3} \quad$ Zechariah 6:1-5 contains elements similar to the other visions: ${ }^{4}$ These elements will help us to understand this vision better.

\begin{tabular}{|c|c|c|}
\hline $\begin{array}{c}\text { Final } \\
\text { Vision }\end{array}$ & $\begin{array}{c}\text { Related } \\
\text { Element }\end{array}$ & $\begin{array}{c}\text { Parallel in } \\
\text { Other } \\
\text { Visions }\end{array}$ \\
\hline $6: 2-3$ & Colored horses & $\begin{array}{c}1: 8 \text { (first } \\
\text { vision) }\end{array}$ \\
\hline $6: 7$ & $\begin{array}{c}\text { Going/coming } \\
\text { to patrol the } \\
\text { earth }\end{array}$ & $\begin{array}{c}1: 10-11 \\
\text { (first } \\
\text { vision) }\end{array}$ \\
\hline $6: 5$ & "All the earth/ & $1: 11 ; 4: 10 ;$ \\
& land" & $4: 14 ; 5: 3 ;$ \\
& & $5: 6($ vision \\
& & $1,5,6,7)$ \\
\hline $6: 1$ & Metal & $5: 7($ lead, \\
(bronze) & & vision) \\
& & $4: 2,12$ \\
& & (gold: fifth \\
& & vision) \\
\hline $6: 1,5,6$ & "Go forth" & $2: 7(2 \mathrm{x}) ;$ \\
$(3 x), 7,8$ & (yasa) & $4: 7 ; 5: 3,4$, \\
& & $5(2 x), 6,9$ \\
& & (visions 3, \\
& & $5,6,7)$ \\
\hline
\end{tabular}

${ }^{3}$ Ibid, 810-811.

${ }^{4}$ Nogalski, The Book of The Twelve MicahMalachi, 878.

${ }^{5}$ David J. Clark, Vision and Oracle in Zechariah 1-

\begin{tabular}{|c|c|c|}
\hline $6: 5$ & $\begin{array}{c}\text { "Winds/ spirits } \\
\text { of the heavens" } \\
\text { and "land of the } \\
\text { north" }\end{array}$ & $\begin{array}{c}2: 6 \text { (third } \\
\text { vision: MT } \\
2: 10) .\end{array}$ \\
\hline
\end{tabular}

\section{A. Layering in the Visions}

A broadly chiastic arrangement of visions can be discerned. The first and eight visions both contain horses and both deal with the Lord's concern for the world at large; they constitute the outer layer.

The second and third visions are both short and relatively simple and both deal with the welfare of Yahweh's people. The sixth and seventh visions are also both short and relatively simple and again deal with the welfare of the Lord's people.

The fourth and fifth visions are longer and more complex; they deal with the leadership of Yahweh's people. They constitute the inner layer. ${ }^{5}$

B. The Discourse Unit: The Eighth Vision $(6: 1-8){ }^{6}$

6:1-3 $1^{\text {st }}$ degree, Division 8, Paragraph 1, Subparagraph 1

I returned and I lifted my eyes and saw, and behold. . .

6:4 I answered and said to the angel who talked with me

6, 530 .

${ }^{6}$ Ibid, 551. 
$2^{\text {nd }}$ degree Interrogative + Vocative: "What are these, my lord?"

6:5-7a Subparagraph 2 And the angel answered and said to me. . .

$2^{\text {nd }}$ degree Answer: These are. . .

6:7b Subparagraph 3 He said

$2^{\text {nd }}$ degree Imperative: "Go, patrol the earth." Narrative 6:8 Subparagraph 4 Then he cried to me, saying $2^{\text {nd }}$ degree Imperative: "See . . . “

\section{Commentary}

Zechariah 6:1-8 could be divided into two sections. First is disclosure of the vision (6:1-4) and the last one is the disclosure and explanation of the vision (6:5-8). Particularly, in this first subparagraph, Zechariah seems to present his thoughts in chiasmus.

A Zechariah's Response: Seeing (6:1a-b).

B Vision: The Chariots (6:1c).

C Vision: The Mountain (6:1d)

B' Vision: The Chariots (6:2-3)

A’ Zechariah's Response: Asking (6:4).

This chiasmus has a structural function which often a chiastic couplet is used to both open and close a stanza or poem. ${ }^{7}$

\footnotetext{
${ }^{7}$ G. E. Watson, Classical Hebrew Poetry: A Guide to its Techniques (London: T \& T Clark, 2005), 205.

${ }^{8}$ Ibid, 288.

${ }^{9}$ I am using the "similar" term in order to present that this construction, three verbs, is utilized in various ways. Firstly, Zechariah abandoned the verb
}

Based on this function, we could see that this chiasmus serves as a marker of a transition of a new vision and first subparagraph, also closes this subparagraph.

A. The disclosure of four chariots $(6: 1-4)$.

v. 1 I returned and I lifted my eyes and saw, and behold, four chariots came out from between two mountains. And the mountains were mountains of bronze.

Zechariah introduced his eighth

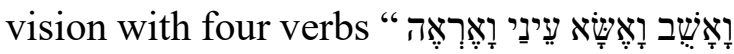

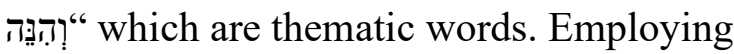
these thematic words has two functions. First of all, it has a function to indicate the structure of the book. ${ }^{8}$

This similar construction appears five times in the book of Zechariah $(2: 5 ; 5: 1$, $9 ; 6: 1) .{ }^{9}$ Four visions, out of eight visions, are commenced by this formula. ${ }^{10}$ This formula not only has a function to signify a new beginning vision but also stressing the attention of the seer by using a series of synonyms on a dominant theme.

It begins with turning himself, lifting his eyes, seeing and, the climax is the revealing of the vision. It could be

\footnotetext{
"שוב" two times in this construction $(2: 5 ; 5: 9)$, when depicting the vision that he saw, though he still maintained the other three verbs. On the other hand, the fuller construction, four verbs, also occurs twice in this book $(5: 1 ; 6: 1)$.

10 Third vision, sixth vision, seventh vision and eighth vision.
} 
understood as hendiadys as well to express an idea of Zechariah's observation of his eighth vision.

This vision is classified as vision present which is a past action or event as happening before Zechariah's eyes. Carson describes that the vision present has a function to place the speaker on the spot where the action or event happens, and by causing him to assume the direction of what takes place.

Through this vision, the speaker could direct his audience's attention on important occasions. ${ }^{11}$ The vision is

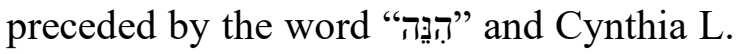
Miller-Naude mentioned that this "הְִּּה " has a function to point to the cognitive effects on a character (or less often the speaker himself/herself) of an observation or mental consideration. הִגנה is a narratorial device to present only a character's visual perception. $^{12}$ In Zechariah's case, הִּנּה indicates that he was confronted with a new vision (the change of scene) which was surprising to him.

The vision is that four chariots came

\footnotetext{
${ }^{11}$ Alexander Carson, Examination of the Principles of Biblical Interpretation, (New York: Edward H. Flecther, 1855), 407-408.

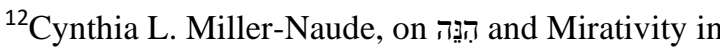
Biblical Hebrew, 70-71

13 Though it is pretty rare that chariot is spoken of as used for peaceful purposes. Further discussion, see Easton Bible Dictionary.
}

out from between two mountains. These chariots are likely vehicles that are generally used for warlike purposes $(6: 8) .{ }^{13}$ The chariots drawn by horses also evoke military images, and in this instance the chariots should be conceived as part of YHWH's heavenly host.

The usage of numeral four implies the number of cosmic (universal) completeness, as in the earth's four corners and four winds. ${ }^{14}$ It means that the military chariots of God are going out to take control of the universe and bring the punishments that come from YHWH. The usage of participle "going out" here seems to vividly portray the situation in the vision. ${ }^{15}$

Imagery of two mountains has had a long pictographic history, as seen in Mesopotamian cylinders. This portrays the sun-God, Shamash who has rays rising from his shoulder, is busy cutting his way through two mountains in order to rise at dawn, while other deities watch. ${ }^{16}$

However, in the book of Zechariah, God's messengers, and not God himself, who are travelling in the chariots.

\footnotetext{
${ }^{14} \mathrm{G}$. K Beale, The Book of Revelation. The New International Greek Testament Commentary. (Grand Rapids: Eerdmans, 1999). 59.

${ }^{15}$ Bruce K. Waltke and M. O'Connor, An Introduction to Biblical Hebrew Syntax (Winona Lake: Eisenbrauns, 1990), 243.

${ }^{16}$ Nogalski, The Book of The Twelve MicahMalachi, 876.
} 
Furthermore, several seals from the ancient Near East illuminate the meaning of the two mountains as the holy place where the deity's world meets the human world. The Lord himself, who is in heaven, has intervened into the human world through his messengers.

The vision of four chariots which came out from between of two mountains is

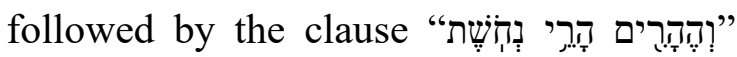
which is verbless clause and in predicate adjective position. The verbless clause itself, according to Wolde, has a function to present background information in which a situation, circumstance, or event is depicted that occurs simultaneously with the sequence of actions expressed in the preceding foreground clause. ${ }^{17}$

Therefore, this verbless clause provides background information about two mountains which the chariots were going out from. In predicate adjective position, the subject "וְָּהָהרים" is the grammatical point of reference for what is talked about in a clause. On the other hand, the predicate "mountains of bronze" is the semantic communication about the subject. ${ }^{18}$ Since "וֹהָהָרִים" is pragmatically marked and has

\footnotetext{
${ }^{17}$ Ellen van Wolde, "The Verbless Clause and Its Textual Function" in the Verbless Clause in Biblical Hebrew (Winona Lake, IN: Eisenbrauns, 1999), 330.

${ }^{18}$ Randall Buth, "Word Order in the Verbless
}

salient information (Focus), then it could be understood that mountains of bronze serves as new information that is specially marked to fill in or to complete "two mountains".

Intertextuality helps the reader to understand the description of the mountain's bronze. It connects this verse with the two bronze pillars that stood at the entrance of Solomon's temple (1 Kgs 7:13-22). These pillars formed part of the entrance to the temple and had the names Jachin and Boaz.

By this analogy, the two bronze mountains of Zechariah's vision are understood to be the heavenly counterparts of these bronze pillars, forming the entrance to the heavens. This seems a more likely connection since the temple was an earthly representation of the cosmos, and the pillars outside the holy place therefore represented the entrance to the visible heavens. ${ }^{19}$

The imagery of the two mountains of bronze, in all likelihood, suggest these messengers (heavenly beings) are leaving the heavenly temple "to patrol the earth" after having reported to YHWH (6:5).

Wright also says that apocalyptic writers speak of a great new act which God will perform on the historical stage in the

\footnotetext{
Clause" in the Verbless Clause in Biblical Hebrew (Winona Lake, IN: Eisenbrauns, 1999), 80.

${ }^{19}$ G.K Beale, “The Temple and the Church's Mission: A Biblical Theology of the Dwelling Place of God", in NSBT 17 (Leicester: Apollos), 29-59.
} 
world. ${ }^{20}$ God involved in human history through his servants.

v. 2 The first chariot were red horses, the second chariot were black horses,

v. 3 The third chariot were white horses, and the fourth chariot were dappled horses--all of them strong.

After providing a background of two mountains, the narrator went back to the discussion of chariots (6:2-3). He presented in same characteristics in verse 2 and 3 such as they employ verbless clause, a particle $ב$ in front of chariot and, the description from one chariot to another chariot, was connected by particle . This particle $\mathrm{Z}$ has a function as, according to Jenni, locative (or place). ${ }^{21}$

Furthermore, this preposition in verse 2-3 clarifies the surfaces (area) of the object (flächenangegenständen) particularly. $^{22}$ Applying this information, the usage of preposition $\beth$ of Zechariah serves to describe the surface and outlook of each chariot in his vision. Verbless clauses give more distinctiveness of every chariot. The type of verbless clause here is noun phrases as predicate complements in verbless

\footnotetext{
${ }^{20}$ Ellen van Wolde, "The Verbless Clause and Its Textual Function", 298.

${ }^{21}$ Ernst Jenni, Die hebraischenPrapositionen Band

1: Die Praposition Beth (Stuggart Belin Koln:

Verlag W. Kohlhammer, 1992), 178-179.

${ }^{22}$ Ibid, 191.

${ }^{23}$ Cameron Sinclair, "Are Nominal Clauses a

Distinct Clausal Type?" in the Verbless Clause in
}

clauses. $^{23}$

The chariot (noun) and ordinal number (adjective) is the grammatical point of reference for what is talked about in a clause. This ordinal number functions as an attributive adjective of chariot in order to identify the noun. ${ }^{24}$ The same case applies to predicate nominative (SC) of horses (noun) and the color (adjective).

\begin{tabular}{|c|c|c|c|}
\hline \multicolumn{4}{|c|}{ Verbless Clause 6:2-3 } \\
\hline Noun & $\begin{array}{c}\text { Attributive } \\
\text { Adjective }\end{array}$ & $\begin{array}{c}\text { Attribut } \\
\text { ive } \\
\text { Adjecti } \\
\text { ve }\end{array}$ \\
\hline Chariot & $\begin{array}{c}\text { Ordinal } \\
\text { Number }\end{array}$ & Horses & Color \\
\hline
\end{tabular}

Therefore, the colors in these verses serve the identifying the horses and, for the whole clause, probably to provide focus in terms of distinguishing and characterizing each chariot. However, the colors of the horses may also symbolize various aspects of judgment, perhaps ward and bloodshed in the case of the red horses, famine and death for the black, victory and triumph for the with $(1: 8 ;$ Rev. 19:11, 14) and plague and disease for the dappled (Rev. 6:1-8). ${ }^{25}$

Biblical Hebrew, 63.

${ }^{24}$ R. J. William, Hebrew Syntax: An Outline. $2^{\text {nd }}$. Ed. Toronto (Toronto: University of Toronto Press, 1976), 21. 
The transition from one chariot to another chariot is marked by preposition $\mathrm{I}$ to denote the sequence of the chariot. In regard to Waltke and O' Connor category, it seems disjunctive waw because the waw before a non-verb constituent. This waw is used by the narrator when he shifts a scene or participant shift. $^{26}$ In short, the narrator shifts the description of one chariot to another one by using this disjunctive waw.

Since William mentions that predicate adjective in non-verbal clauses normally precede their substantives with concord of gender and number, but are regularly anarthrous, ${ }^{27}$ then the word

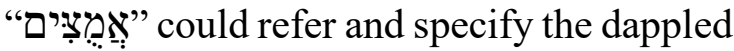
horses only or all of the horses. However, the appearance of tipha under " denotes disjunctive between this word and next word. In this passage, the same pattern also appears in Zechariah 6:4 and 6:7. On the other hand, if this word was meant to be read as unity, the accent mereka would be

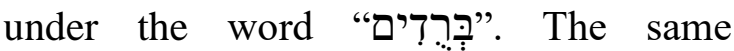
construction occurs in Zechariah 6:1-2; 5-6; 8. Zechariah 6:1 is one of the examples that I have listed. The mountains are going together with bronze because of the conjunctive accent mereka. This

\footnotetext{
${ }^{26}$ Waltke and O'Connor, An Introduction to Biblical Hebrew Syntax, 651-652

${ }^{27}$ William, Hebrew Syntax: An Outline.
}

conjunctive accent would support the

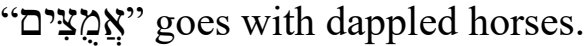

However, the disjunctive accent,

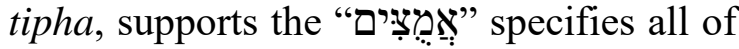
the horses. The second argument is the structure in Zechariah 6:7. This staircase parallelism in this verse has a function to assist the segmentation of the speech. These three segmentations have a purpose to help the reader to recognize the progressive (escalation) of the story.

The first line of parallelism describes the willingness of horses to go and patrol the earth. It escalates when God gives permission for them to patrol the earth. The climax of this verse is while they executed the order to go. Based on this staircase parallelism, we could understand that the strong in verse 7 does not refer to one chariot only, but to all of the chariots. ${ }^{28}$

The last argument is the context of Zechariah 6:8. The narrative flow of this vision denotes that all of the chariots patrolled the earth because of God's permission. The result is those, who are going to the north (both black and white horses), have appeased His wrath (6:8).

It implies that all the chariots went to the earth because of God's permission to the strong ones. Therefore, we could say

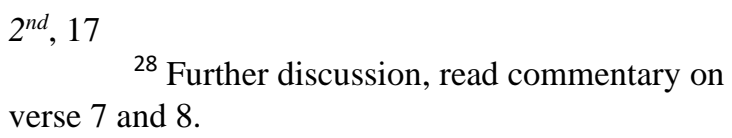


that the strong ones are the same with all chariots. In respect to these three arguments, the characteristic "strong" is understood to identify the whole chariots. Although they have different colors and duties, they have the same quality of strength.

\section{v. 4 Then I answered and said to the} angel who talked with me, "What are these, my lord?"

One of features of Zechariah's vision is the occurrence of dialogue, often but not always in the form of question and answer. Nevertheless, in this part, the occurrence of dialogue in form of question and answer appears. The prophet opens the dialogue by asking the angel for interpretation $(1: 9 ; 2: 2 ; 4: 4 ; 5: 6)$. The question is introduced with the use of the verb "ענה", even though it is the first utterance of the vision: "I replied and said . . ."Zechariah used thematic words, וזאמֵַר, again in this verse which informs the end of this subparagraph.

Preposition "אֶר" expresses action (motion) of Zechariah towards the angel.

\footnotetext{
${ }^{29}$ Bauckham articulates the important of angel with respect to vision in Jewish literature. Old Testament pictures that angel of God as the agent of visionary experience is pretty common (Num. 24:2, $4,16-17)$, though probably also implied in general references to ecstatic prophecy (Num. 11:24-29; 1 Sam. 10:6, 10). In later Jewish literature, the angel of Yahweh inspires prophetic speech (1 Enoch 91:1; Jub. 25:14; 31:12; Pesudo-Philo, LAB 18:11; 32:14; 4 Ezra 14:22), as the agent of visionary transportation (2 Bar. 6:3; Hebrew ApEl) and
}

The presence of angels here is one characteristic of apocalyptic literature. ${ }^{29}$ The seer is invited by the angel to view a wide range of things normally hidden, including secrets of the heavens and the earth, the beginning and the end of things. This has purposes to lead the seer to a full understanding and worship of the one God. ${ }^{30}$ In the book of Zechariah, the angel of God is likely a translator of this vision. This idea is endorsed by the book of Zechariah itself. This phrase occurs 11 times in this book $(1: 9,13,14 ; 2: 2,7 ; 4: 1$, $4,5 ; 5: 5,10 ; 6: 4)$ and indicates that the angel of the Lord has a duty as an interpreter.

"הָדברר" ", after the word angel, is used as the equivalent to a relative clause because this participle is preceded by article,${ }^{31}$ and it has a function to identify the angel and expressing a habitual or abiding state (activity). Based on this information, this kind of participle is ideal for occupation or profession. It endorses the idea of the angel of the Lord as an interpreter the prophetic message to Zechariah.

possibly once as the agent of translation into heaven (1 Enoch 70:2). See Richard Bauckham, The Climax of Prophecy (T\&T Clark Edinburgh, 1993), 154.

${ }^{30}$ N. T. Wright, The New Testament and the People of God. Volume one of Christian Origins and the Question of God (Minneapolis: Fortress Press, 1992), 282.

${ }^{31}$ William, Hebrew Syntax: An Outline. $2^{\text {nd }}, 40$. 
The preposition "ב" here, according to Jenni, has two meanings. Firstly, it denotes the local-directional connotation. Then, the usual translation would be "the angel that talked with (before) me to me". Moreover, Jenni argues that this preposition here also has connotation of prophetic instrumental usage. This prophet is the instrument for the prophetic in terms of his deputy is to address the prophetic message. ${ }^{32}$ Therefore, the angel communicated and disclosed the divine revelation before Zechariah and through him as an agent and mediator of this message to God's people.

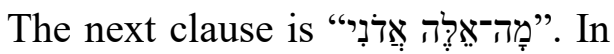
this clause, the predicate (syntactic predicate) is the interrogative pronoun "מָז". On the other hand, "אִלְה אִּנדני" is the nominal sentence (syntactic subject). "אליה" is

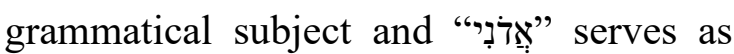
grammatical complement. This sentence is marked since the element occupying first place is a pronoun (a particular term).

Then, the emphasis falls on the particular term or nonverbal element that occurs in first position, which is not

${ }^{32}$ F. Merrill Unger, Zechariah (Grand Rapids: Zondervan Publishing House, 1963), 164165

${ }^{33}$ AlvieroNicacacci, Types and Function of the Nominal Sentence, the Verbless Clause in Biblical

Hebrew, 245. expected in the function of the predicate. This element is promoted to the role of syntactic predicate. ${ }^{33}$ Furthermore, "מָּה" inquires the nature or kind of the object. ${ }^{34} \mathrm{It}$ means that the emphasis of this sentence is on the interrogative pronoun to describe the characteristics of four chariots which are condensed by one word of demonstrative pronoun "אלקה". In this case, this demonstrative pronoun is used as enclitic to emphasize interrogative words. ${ }^{35}$

The grammatical complement, "אַדנִי", has a function to address this

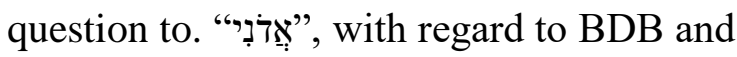
HALOT, most likely this has the similar meaning of 'Lord' in two different contexts which refer either to YHWH, or to beings of higher respect or authority from the speaker, such as masters or angels.

The book of Zechariah defines the usage of "which when appears seven times. Five of them are used in the vision's context and they always refer to the angel $(1: 9 ; 4: 4$, $5,13 ; 6: 4)$. In contrast, the rest emerges outside of vision's context and relates to Yahweh (1:7; (9:4). Consequently, Zechariah asked the messenger, who is

\footnotetext{
${ }^{34}$ Georg Heinrich Ewald, Syntax of the Hebrew Language of the Old Testament (Eugene, Oregon: Wipf and Stock Publishers, 2004), 196.

${ }^{35}$ E. Kautzch, Gesenius'Hebrew Grammar, tr. By A. E. Cowley, $2^{\text {nd }}$ edition (Oxford University Press, 1910), 442.
} 
highly respected, to explain this kind of vision that he just saw.

B. The explanation of the vision (6:5-8).

This is the final vision in the sequence of eight visions that began in 1:7. It rounds out the sequence nicely with the number of connections back to the opening visions and the resolution of themes raised there. In the first vision, there was a single rider on a chestnut horse, with a group comprising multiple chestnut, sorrel and white horses that patrolled the earth and returned with the lamentable news that the earth, rather than God's people (1:11), was "at rest" (soqatet). In this final vision, there are four groups of coloured horses (red, black, white and dappled), this time with chariots, that are sent out to patrol the earth and in doing this "appease" (henihu) God's wrath in the land of the nations $(6: 8)$. The second and third visions envision the coming destruction of the nations, particularly Babylon, "the land of the north" (2:6/ MT 2:10). In this vision, "the land of north" is finally judged $(6: 8){ }^{36}$

This vision is dominated and could be divided by three utterances in chiasm. ${ }^{37}$

\footnotetext{
${ }^{36}$ Petterson, Haggai, Zechariah \& Malachi, 174.

${ }^{37}$ Ibid, 550.

${ }^{38}$ E. Kautzch, Gesenius 'Hebrew Grammar, 327.

${ }^{39}$ From Zechariah to the angel.
}

If the first section chiasm is based on the seer and the things that he saw, this section depends on the speaker and the people whom he talked with.

A The Response: To the prophet (6:5-7a).

B The Response: To the horses (6:7b).

A' The Response: To the prophet (6:8).

v. 5 And the angel answered and said to me, "These are going out to the four winds of heaven, after presenting themselves before the LORD of all the earth.

Verse 5 is initiated with the waw

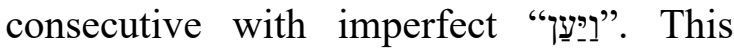
construction serves to express action, events or states which are to be regarded as temporal sequels of action, events, or states mentioned immediately before. ${ }^{38}$ In short, this construction is a signal for temporal sequence in response to Zechariah's question. On the other hand, based on its context, it could serve as a disjunctive marker to change the main actor, ${ }^{39}$ topic and scene. ${ }^{40}$ Although verse 5 commences a new setting, the narrator maintains the pattern of sentence, ${ }^{41}$ and the vocabularies of the previous verse ${ }^{42}$ to smooth the

\footnotetext{
${ }^{40}$ From question to explanation.

41 (S-V-O-IO)

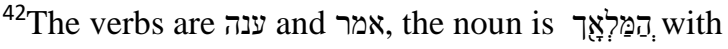

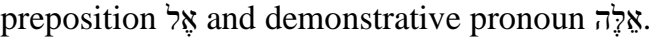


transition and for stylistic reasons.

The messenger here has an article to indicate definiteness when the person has already been mentioned (the same person) in the previous verse that Zechariah talked to. ${ }^{43}$ The narrator uses two verbs that belonged to angels.

The verbs "עמר" "ענה" are successive parallelisms of components because the type of hendiadys comes in the form of two verbs in immediate succession. ${ }^{44}$ This hendiadys has a function to evoke a word-pair that communicates a single idea which is communication with the angel as the main actor. The preposition "אֶ," here has a function to address the recipient whom the angel has been communicating with.

The very first word of messenger is demonstrative pronoun "אֶלֶה". This demonstrative pronoun always refers to a person or thing that is already mentioned or known. ${ }^{45}$ This demonstrative pronoun (v. 5) is used to answer the question in demonstrative pronoun (v. 4) which summarizes the vision (v. 1-3).

אַרבַּע is an abstract substantive of cardinal number. Since it goes with " רחוֹת become inflected for gender

\footnotetext{
${ }^{43}$ William, Hebrew Syntax: An Outline. $2^{\text {nd }}, 18$.

${ }^{44}$ Watson, Classical Hebrew Poetry: A Guide to its Techniques, 326.

${ }^{45}$ E. Kautzch, Gesenius 'Hebrew Grammar, 442.

${ }^{46}$ Ibid, 432
}

and is used in the construct state. ${ }^{46}$ Therefore, it serves to give more information (in numeral) to the bound

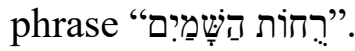

In apocalyptic literature, number four is pretty significant in the book of Zechariah because this number has been used also in several other visions. In the second vision, for instance, "four" seems to represent the entirety of the world since the "four horns" signify all the nations on earth that scattered God's people $(1: 19 ; 2: 2)$. The "four craftsmen" simply correspond to the horns who cast them down $(1: 20 ; 2: 3)$. Hence, in this context, the number "four" seems to represent "the four compass directions and thus the entire world". ${ }^{47}$ It corresponds with the description "the Lord of the whole earth" (6:5).

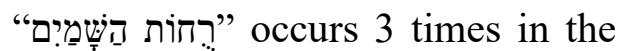
Old Testament. ${ }^{48}$ Intertextuality informs more clearly in terms of a duty of four spirits of heavens but doesn't provide their identities. Daniel 7:2 depicts that these creatures were stirring up the great sea and they caused four great beasts to come up from the sea. Daniel's interpretation is these great beasts represent four kings who will arise from the earth (Dan. 7:17) and they

\footnotetext{
${ }^{47}$ C.L. Meyers and E.M. Meyers (1992), 'Zechariah, Book of (Zechariah 1-8)', in ABD 6:317.

${ }^{48}$ One appears in this verse, the rest are in the book of Daniel (Dan. 7:2).
} 
will devour the whole earth (Dan. 7:23).

Therefore, we could assume that the duty of four spirits of heavens is causing the kings to rise up and rule the earth. In short, they will replace one kingdom to another kingdom. On the other hand, the book of Zechariah provides the identity of fours spirits. They are the messengers of God who were commissioned by God to patrol the earth and to punish those nations that they see oppressing God's people (Zech. 6:5-8).

Because "יוֹצִּאוֹת" is a participle in subject-verb pattern in this clause, it describes a prevailing situation. ${ }^{49}$ This participle exhibits its adjectival origin in its essential use to express circumstances, states of affairs, facts, etc., rather than events. In construct state, this participle governs the four spirits of heaven. It depicts the situation or state of four spirits of heaven that were going out.

This preposition "מ̣ן" has a function of separative and informs two separations based on the context. First separation is the discontinuity of activities, from standing to going out. The last segregation is the transition of the place, from before Yahweh to the earth. "After presenting themselves" phrase also evokes the reader's mind that the spirits as a part of heavenly council (1 Kgs. 22:21-23).

\footnotetext{
${ }^{49}$ Sue Groom, Linguistic Analysis of Biblical
}

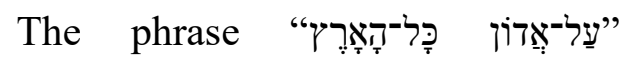
appears twice in the book of Zechariah $(4: 14 ; 6: 5)$. Although the narrator used the same word wָדוֹן with previous verse, it communicates the different person. Preceding verse refers to angels, but this verse pertains to Yahweh. It is endorsed not only from the book of Zechariah itself that always refers to Yahweh (by its context) but also the rest of Old Testament (Jos. 3:11; 3:13; Psal. 97:5). Anyone who reads this phase from the book of Joshua evokes the memory of three important lessons.

Firstly, Joshua invites the people of God to listen to the words of Yahweh and remember the covenant of God before entering to a promised land $(3: 9 ; 11)$. This book also declares that God is living among the people in the midst of their difficult circumstances such as they had nothing in terms of land and were surrounded by wicked nations (3:10a). The last lesson is Yahweh as the powerful God. He is the one who gives and dispossesses the land (3:10b).

The psalm also uses this phrase when declaring the glory of God's reign above the earth and heavens (Psalm. 97). Based on these allusions, it could be understood that Zechariah wants these people of God to remember God's covenant

Hebrew (Cumbria: Paternoster Press, 2003), 145. 
and words in the midst of their miserable life after returning back from exile because God is living among them. At the end, Yahweh will restore their condition and punish their enemies because he is the true king of heaven and earth (Zech. 6:5-8).

v. 6 The one with the black horses - they are going to the North country, the white ones go after them, and the dappled ones go toward the south country."

This verse is initiated with a relative clause. This relative clause, like adjectives, adverbs and prepositional phrases, are syntactically classified as adjuncts, that is, expressions providing additional information about the antecedent activity/event/noun. ${ }^{50}$ The question is whether this clause provides further information to the subject (the spirits) or object (Lord) in direct speech from the previous verse.

Since this relative is resumed in the qualifying clause by the subjects in Zechariah 6:6-7a, then we could see that "ָָשֶׁר" is added in apposition to one of four spirits of heavens. In brief, this relative pronoun presents information to the spirit

\footnotetext{
${ }^{50}$ Robert D. Holmstedt, The Relative Clause in Biblical Hebrew a Linguistic Analysis, (Madison: University of Wisconsin), 2002), 60.

${ }^{51}$ E. Kautzch, Gesenius 'Hebrew Grammar, 305, 444-445
}

and stands in nominative position. Because

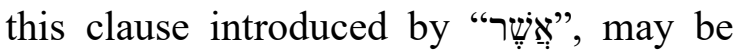
called independent relative clause, it expresses a substantival idea, ${ }^{51}$ so that the literal translation would be "the one (in which) were".

Preposition ב ב:: with suffix third person feminine singular and this relative pronoun appears in 18 verses in the Old Testament. ${ }^{52} 17$ times occur in the narrative genre and the translation is always "were (was) in it". Those occurrences exhibit that

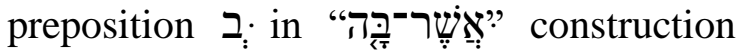
always refers to location and the suffix always goes to the place that has been mentioned in preceding verse (agrees in number and gender). Therefore, it has a

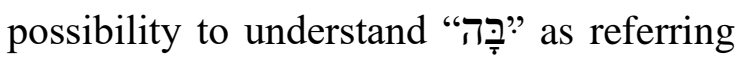
to location and based on the context, the location is on the earth because it also concurs with the number and gender of the earth.

However, the Hebrew represents a grammatical anacoluthon; the subject at the beginning of the sentence is the first chariot (feminine singular), and then becomes the black horses which draw it (masculine

\footnotetext{
${ }^{52}$ Num. 32:39; Deu. 10:14; 13:16; Jos. 6:17, 24; 10:28, 30, 32, 35, 37, 39; 11:11; Jdg. 9:45; 1 Sam. 30:2; 2 Sam. 12:31; 2 Kings 15:16; 1 Chr. 20:3; Zech. 6:6
} 
plural). ${ }^{53}$

The subsequent question of this construction is whether this relative particle may be used in either restrictive or nonrestrictive relative. The presence of a head noun, one of four spirits of heavens, in construct state indicates that this pronoun is employed in restrictive relative. ${ }^{54}$ Thus, this restrictive relative provides information about its head which is necessary for identifying the exact referent of the head.

Verse 5 mentions that the four spirits of heavens went out from the presence of God. In this verse, restrictive relative pronounces important information to the readers by stating that one of them is going already to the North. This restrictive relative gives the escalation of place movement from the previous verse, and also serves to give general information for the next clause. The disjunctive accent "garsajim" on

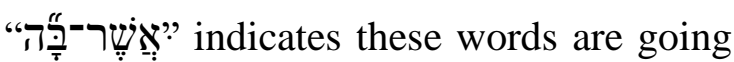
together and will begin another clause.

Based on observation of the structure of this vision, the narrator changed the objects of vision a few times for stylistic reasons.
A: Four Chariots $(6: 1)$
B: Further Description: Horses (6:2-4)
A: Four Spirits of Heavens (6:5)
B: Horses (6:8).

\footnotetext{
${ }^{53} \mathrm{Al}$ Wolters, Historical Commentary on the Old Testament "Zechariah", (Belgium: Leuven, 2014), 175.
}

\begin{tabular}{|l|l|l|}
\hline \multicolumn{1}{|c|}{$6: 1-4$} & \multicolumn{1}{|c|}{$6: 5$} & \multicolumn{1}{c|}{$6: 6-8$} \\
\hline 1: Four & 5: Four & \\
Chariots & $\begin{array}{l}\text { Spirits of } \\
\text { Heavens }\end{array}$ & \\
\hline $\begin{array}{l}\text { 2-4: The } \\
\text { Further } \\
\text { Descriptio } \\
\text { n of Four } \\
\text { Chariots : }\end{array}$ & & 6-8: Horses. \\
Horses & & \\
\hline
\end{tabular}

In the midst of the appearance of chariots and horses throughout this vision, there is a different object: four spirits of heavens. Based on this stylistic pattern, it is likely four spirits of heavens are interpretations of chariots that came out from two bronze mountains. This idea is suitable with apocalyptic literature which stresses that every event that occurs in the earth, it comes from heavens. It has been predetermined and decreed by God.

After explaining the identities of the chariots and the place which they came from, the narrator switched again to horses to describe the duty and destination of the horses. The following clause has a function to give further information which is summarized in the table below.

\footnotetext{
${ }^{54}$ Holmstedt, The Relative Clause in Biblical Hebrew a Linguistic Analysis, 119-120.
} 


\begin{tabular}{|c|c|c|c|c|}
\hline & $\begin{array}{l}\text { Chariot } \\
(6: 6-7 a)\end{array}$ & The Verb & $\begin{array}{c}\text { Destinati } \\
\text { on }\end{array}$ & $\begin{array}{c}\text { Comparison } \\
\text { Chariot (6:2-3) }\end{array}$ \\
\hline 1 & $\begin{array}{l}\text { The } \\
\text { black } \\
\text { horses }\end{array}$ & $\begin{array}{c}\text { qal } \\
\text { participle } \\
\text { masculin } \\
\text { e plural }\end{array}$ & North & Red horses \\
\hline 2 & $\begin{array}{c}\text { The } \\
\text { white } \\
\text { horses }\end{array}$ & $\begin{array}{c}\text { qal } \\
\text { perfect } \\
\text { 3rd } \\
\text { person } \\
\text { plural }\end{array}$ & $\begin{array}{l}\text { Go } \\
\text { after } \\
\text { them } \\
\text { (Imply } \\
\text { North) }\end{array}$ & Black horses \\
\hline 3 & $\begin{array}{c}\text { The } \\
\text { dappled } \\
\text { horses }\end{array}$ & $\begin{array}{c}\text { qal } \\
\text { perfect } \\
\text { 3rd } \\
\text { person } \\
\text { plural }\end{array}$ & South & White horses \\
\hline 4 & & & & $\begin{array}{c}\text { Dappled } \\
\text { horses }\end{array}$ \\
\hline 5 & $\begin{array}{l}\text { The all } \\
\text { the } \\
\text { strong } \\
\text { horses }\end{array}$ & $\begin{array}{c}\text { qal } \\
\text { perfect } \\
\text { 3rd } \\
\text { person } \\
\text { plural }\end{array}$ & $\begin{array}{l}\text { Patrol } \\
\text { the } \\
\text { earth }\end{array}$ & $\begin{array}{l}\text { All of them } \\
\text { strong }\end{array}$ \\
\hline
\end{tabular}

All of the clauses are presented in noun (nominal) clause. It means that the subject of a nominal clause is the initiator or "that which begins" and this construction promotes the initiator as the focal point of the clause, especially its identity, character and description. As a result, the subject in this nominal clause serves to identify the horses and, for the whole clause, probably to provide a focal point of the clause in terms of distinguishing and characterizing each color of horses. The transition from one colored of horses to other horses is marked by preposition I to denote the sequence of the colored horses. In regard to Waltke and O' Connor category, it seems disjunctive waw because the waw before a non-verb constituent. This waw is used by the narrator when he shifts a scene or participant shift. ${ }^{55}$ In short, the narrator shifts the description of one colored horse to another one by using this disjunctive waw.

From the table of verbs, qal participle only occurs once in the black horses and the rests are utilizing qal perfect form. The usage of qal participle has been employed three times in this section $(6: 1,6$, 8). Structurally, it seems to have a function to summarize the whole of eighth vision. In verse 1, this qal participle depicts the beginning of the vision. ${ }^{56}$ It continues to the middle of vision on which the horses are going to the North (v. 6).

This qal participle ends the story of this vision by informing the result of the activities of black horses. In conclusion, the usage of qal participle in the midst of four qal perfect has a function to signal distinctness and focus to this color of horses which is related to the North. It is supported by the function of qal participle to vividly portray the situation in the vision, instead of qal perfect which emphasizes on completed states.

In the chariot column above, the red horses are missing. Constable says that it is likely that the red horses went south too,

\footnotetext{
56 The four chariots are going out from two mountains.
}

${ }^{55}$ Waltke and O'Connor, An Introduction to Biblical Hebrew Syntax, 651-652. 
following the dappled horses. ${ }^{57}$ This interpretation is possible when considering the geography of Palestine. Nevertheless, it is enough to say that the focus of this narrative is judgment to the north. ${ }^{58}$

On the destination column, the narrator doesn't mention both east and west, though number four represents the entirety of the world. In this verse, the geography plays important role. Because of the geography of Palestine, all of Israel's enemies came against her from north or south. The east of Israel and Judah is Arabian deserts; on the other hand, the west side is Mediterraneasea. The appellation of North and South is also related to geography.

Old Testament prophetic texts display on going tradition of the threat from the north country. The north country is the place from which attacks come from Assyria and Babylon (Isa. 14:31; Jer. 1:1415; 6:1, 22; 15:12; 46:20, 24; Ezek. 26:7; 38:6; 39:2; Zeph. 2:13). ${ }^{59}$ For the South, it probably refers to Egypt (Is. 43:6) and it was another implacable enemy. The usage of the word "earth" in this verse has different meaning with verse 5 , because the location

\footnotetext{
${ }^{57}$ http://www.soniclight.com/constable/notes/pdf/ze chariah.pdf

${ }^{58}$ Further arguments, see verse 8 .
}

(both North and South) has a function to limit the scope of earth. Therefore, we could translate "אֶרִץ" as country.

There is no particular destination for white horses. The narrator only mentions

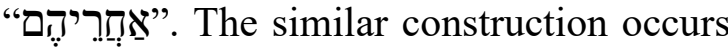
three times in the Old Testament (2 Sam. 5:23, 2 Kings 9:18, 19). ${ }^{60}$ All of these constructions denote that the subject follows the previous subject to the same place (position). Although the narrator doesn't provide a specific area of the

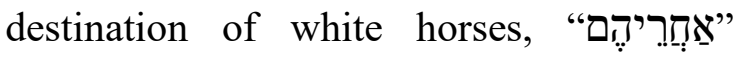
implies that the white horses were going after the black horses to the same direction (North).

Stylistic in writing (A-B-A-B) is the reason for omission of the particular destination of white horses. ${ }^{61}$ Based on the destination column, the narrator deliberately depicted two contrasted colors, black and white, which went to the North. These contrasted colors and the number of horses seem to have a function to emphasize on the certainty of punishment and destruction in the North $(6: 10)$.

\section{v. 7 When the strong horses came out,}

\footnotetext{
${ }^{59}$ Nogalski, The Book of The Twelve MicahMalachi, 877.

${ }^{60}$ Based on categorization of BDB.

${ }^{61}$ A refers to specific areas such as North and South. On the other hand, B has a characteristic of ambiguousness (after them and the earth).
} 
they sought to go and patrol the earth. And he said,

"Go, patrol the earth." So they patrolled the earth.

This verse exhibits staircase parallelism by providing 3 fold of same words.

\begin{tabular}{|c|}
\hline 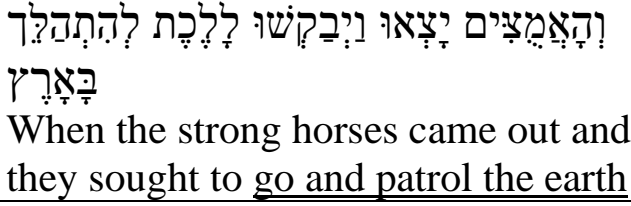 \\
\hline 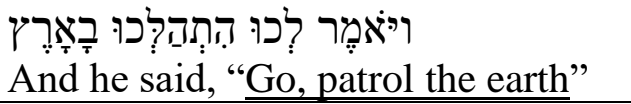 \\
\hline 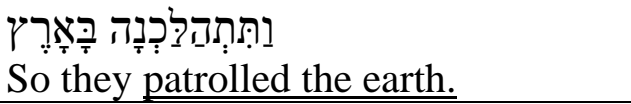 \\
\hline
\end{tabular}

This staircase parallelism has a function to assist the segmentation of the speech. ${ }^{62}$ These three segmentations have a purpose to help the reader to recognize the progressive (escalation) of the story. The first line of parallelism describes the willingness of horses to go and patrol the earth. It escalates when God gave permission for them to patrol the earth. The climax of this verse is while they executed the order to go.

On this verse, the word "הלך" appears five times, out of seven verbs, indicates that the theme of "הלך" is pretty dominant in this verse. From the book of Zechariah, the theme of "הלך" also occurs in the first vision, but presenting slightly

\footnotetext{
62 Watson, Classical Hebrew Poetry: A Guide to its Techniques, 154.
}

different information. In the first vision, God is the one who sent them to the earth (1:10). In the eighth vision, the narrator mentioned that the horses wanted to go as well by using the word "בקש" (6:7a).

The end of their patrolling in first vision is the report that all the earth is peaceful and quiet (1:11). Interestingly enough, the end of their patrolling in the last vision is appeasing His wrath (6:8). Both of them have the same result: peaceful, but different objects (the earth is in contrast to God). Therefore, the idea of patrolling here is when the messengers of God intervened in human (earthly) affairs. The usage of "הלך" in this verse is summarized by the table below.

\begin{tabular}{|c|c|c|c|}
\hline $\begin{array}{c}\text { The } \\
\text { Message }\end{array}$ & Qal & Hithpael & $\begin{array}{c}\text { The } \\
\text { Location }\end{array}$ \\
\hline $\begin{array}{c}1 . \text { The } \\
\text { Purposes } \\
\text { (7b) }\end{array}$ & $\begin{array}{c}\text { In } \\
\text { infinitive } \\
\text { construct }\end{array}$ & $\begin{array}{c}\text { In infinitive } \\
\text { construct }\end{array}$ & $\begin{array}{c}\text { Preposition } \\
\text { ב:and earth }\end{array}$ \\
\hline $\begin{array}{c}2 . \text { The } \\
\text { Command } \\
(7 \mathrm{c})\end{array}$ & $\begin{array}{c}\text { In } \\
\text { imperative }\end{array}$ & In & $\begin{array}{c}\text { Preposition } \\
\text { impative }\end{array}$ \\
\hline $\begin{array}{c}\text { 3. The } \\
\text { Activity } \\
\text { (7d) }\end{array}$ & & In imperfect & $\begin{array}{c}\text { Preposition } \\
\text { ב-and earth }\end{array}$ \\
\hline
\end{tabular}

The basic meaning of "הלך" in qal is to go or walk. On the other hand, hithpael has meaning of reflexive of piel, reciprocal action, an action less directly affecting the subject or passive. ${ }^{63}$ Based on these basic meanings, no one is matched with the

${ }^{63}$ E. Kautzch, Gesenius 'Hebrew Grammar, 149150 . 
meaning of hithpael in this verse. However, Gesenius says that the modification of the original meaning becomes especially evident when reflexive conjugations (niphal, hithpael) take an accusative. ${ }^{64}$ Consequently, the new meaning of "הלך" in hithpael is to go to and fro.

The preposition "?": and infinitive communicate the purpose of their eagerness. These purposes are presented in wordplay which is based on root (rootplay). ${ }^{65}$ They wanted to go and patrol the whole earth. The next clause denotes the order of their patrolling (imperative).

However, there is a question in terms of the person who gave permission, either God himself or the angel of Yahweh. From conversation in Zechariah 6:5, the person might be the angel who was giving a command to the chariots. Nevertheless, the first vision denotes that God, not His angel, is the one who sent them $(1: 10)$. The second argument is in the subsequent verse. Verse 8 mentions that those, who are going to the North, have appeased my wrath. The most plausible interpretation is God's wrath and not the angel. ${ }^{66}$ In conclusion, regardless of the eagerness of horses, they submitted themselves before YAHWEH and waited until God's command to go and patrol. The

\footnotetext{
${ }^{64}$ Ibid.

${ }^{65}$ Watson, Classical Hebrew Poetry: A Guide to its Techniques, 238.
}

last clause is the climax of the theme of “הלך". After exhibiting the eagerness of horses and the approval from God, they patrolled the earth.

\section{v. 8 Then he called out to me and he said} to me "Behold, those who go toward the north country have set my wrath at rest in the north country."

This verse also is presented in two parallelisms. First parallelism is in the narrative section and the parallelism is based on word pair. On the other hand, the second one is in God's speech and it is based on two fold of the same words.

\begin{tabular}{|c|c|}
\hline בוּיזְעַק אִתִי & $\begin{array}{l}\text { Then he called out } \\
\text { to me }\end{array}$ \\
\hline 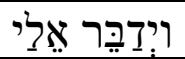 & And he said to me \\
\hline
\end{tabular}

First parallelism is using they דבר - זעק synonymous two word-pairs,

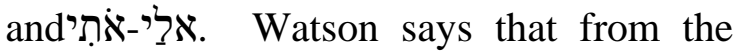
poet's point of view, the main function of parallel pairs was to assist him in composing verse. He mentions as well that the use of word-pairs is not exclusive to oral poetry; the writing prophets, for example, though well-schooled in the tradition of oral poetry, were able to use word-pairs with a certain degree of freedom betokening mastery. ${ }^{67}$

\footnotetext{
${ }^{66}$ More discussion, see commentary in verse 8 .

${ }^{67}$ Watson, Classical Hebrew Poetry: A Guide to its Techniques, 140.
} 
On the other hand, at the linguistic level, it serves as cohesion. ${ }^{68}$ The use of stock wordpairs helps bind together the parallel lines of couplets of this verse.

The word "רֵאה" could serve as a disjunctive marker of this vision. It seems the narrator used synonym of "התפהּה " to close

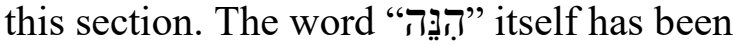
used in all of Zechariah's visions, except fourth vision, as opening marker of a new vision. The usage of "רָה" has a function to give a result of the horsemen that have accomplished their task.

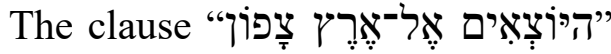
strengthens the idea that the main focus of this vision is related to the north. It does not mean that the other colors or destination are not important. However, the announcement of those who are going to the land of the north only implies that the focal point of this vision is judgment regarding the north.

The narrator played with the ambiguity of the word "רוּ?", which can also mean "wrath". If taken in that sense, the Hiphil of "רוּ:"conveys the idea of appeasing or satisfying God's anger, and thus signifies that his phrase refers to judgment on Babylon. However, "רוּח". can also refer to the divine Spirit, and it that case

68 Ibid.

${ }^{69}$ Wolters, Historical Commentary on the Old the verb could convey the idea of causing the wrath to rest (that is, settle) in Babylon, which suggests blessing rather than judgment. Based on the context, it is clear that this passage talks about judgment. Using the word of chariots, it is understood as an instrument of war. Secondly, the verbal from use here (the Hiphil of "ריף:') is used repeatedly in Ezekiel for the appeasing of God's wrath $(5: 13 ; 16: 42 ; 21: 22$; 24:13). ${ }^{69}$ The next argument is Septuagint uses $\theta u \mu o ́ v$ as wrath.

Therefore, the most plausible word here is wrath instead of spirit. The horses that had gone out into the north had "appeased" His wrath in the land of the north. The land of north probably represents judgment of Babylonia specifically, but it perhaps hints at the total destruction of all enemies of Israel. Babylon had fallen to the Persians 20 years earlier, in 539 B.C.

\section{REFERENCES}

[1] Beale, G.K. The Book of Revelation. The New International Greek Testament Commentary. Grand Rapids: Eerdmans, 1999.

[2] The Temple and the Church's Mission: A Biblical Theology of the Dwelling Place of God, in NSBT 17. Leicester: Apollos.

Testament “Zechariah”,, 178. 
[3] Buth, Randall. Word Order in the Verbless Clause in the Verbless Clause in Biblical Hebrew. Winona Lake, IN: Eisenbrauns, 1999.

[4] Ewald, Georg Heinrich. Syntax of the Hebrew Language of the Old Testament. Eugene, Oregon: Wipf and Stock Publishers, 2004.

[5] Carson, Alexander. Examination of the Principles of Biblical Interpretation. New York: Edward H. Flecther, 1855.

[6] Chia, P. S., \& Juanda, J. (2020). A

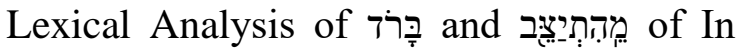
Zechariah 6: 3-5. Journal DIDASKALIA, 3(2), 1-8.

[7] Chia, P. S., \& Juanda, J. (2019). A Textual Criticism and Lexical Analysis of Isaiah 62. Journal DIDASKALIA, 2(2), 813.

[8] Groom, Sue. Linguistic Analysis of Biblical Hebrew. Cumbria: Paternoster Press, 2003.

[9] Holmstedt, Robert D. The Relative Clause in Biblical Hebrew a Linguistic Analysis. Madison: University of Wisconsin, 2002.

[10]Http://www.soniclight.com/constable/n otes/pdf/zechariah.pdf.

[11] Jenni, Ernst Jenni. Die hebraischenPrapositionen Band 1: Die Praposition Beth. Stuggart Belin Koln: Verlag W. Kohlhammer, 1992.

[12] Kautzch, E. Gesenius'Hebrew Grammar, tr. By A. E. Cowley, $2^{\text {nd }}$ edition. Oxford University Press, 1910.

[13] Nogalski, James D. The Book of The Twelve Micah-Malachi. Macon: Georgia: Smyth \&Helwys, 2011.
[14] Petterson, Anthony R. Haggai, Zechariah \& Malachi. Downers, Illinois: InterVarsity Press, 2015.

[15] Unger, F. Merrill. Zechariah. Grand Rapids: Zondervan Publishing House, 1963.

[16] Waltke, Bruce K. and M. O'Connor. An Introduction to Biblical Hebrew Syntax. Winona Lake: Eisenbrauns, 1990.

[17] Watson G.E. Classical Hebrew Poetry: A Guide to its Techniques. London: T \& $\mathrm{T}$ Clark

William, R.J. Hebrew Syntax: An Outline. $2^{\text {nd }}$. Ed. Toronto (Toronto: University of Toronto Press, 1976.

[18] Wolde, Ellen van. The Verbless Clause and Its Textual Function in the Verbless Clause in Biblical Hebrew. Winona Lake, IN: Eisenbrauns, 1999.

[19] Wolters, Al. Historical Commentary on the Old Testament 'Zechariah'.

Belgium: Leuven, 2014.

[20] Wright, N.T. The New Testament and the People of God. Volume one of Christian Origins and the Question of God. Minneapolis: Fortress Press, 1992. 